\title{
Improving hand hygiene compliance in Singapore via innovation
}

\author{
L Ang ${ }^{*}, K L$ Ooi, A Lim, B Ong, P Tambyah, D Fisher \\ From International Conference on Prevention \& Infection Control (ICPIC 2011) \\ Geneva, Switzerland. 29 June - 2 July 2011
}

\section{Introduction / objectives}

The National University Hospital (NUH) is a 997 bed acute tertiary hospital. In 2006, we embarked on a MRSA prevention bundle, the cornerstone of which was a hand hygiene $(\mathrm{HH})$ compliance programme.

\section{Methods}

$\mathrm{HH}$ is a standard for NUH hospital accreditation. In 2007 it became an internal key performance area with alcohol hand rub fitted to the foot of all beds. $\mathrm{HH}$ audits, using the WHO toolkit were conducted by Infection Control Liaison Nurses across hospitals, medical students and staff from our partner health cluster. Ward-specific audit results were displayed publicly in wards. Poor results were reported to nominated senior clinical 'HH Champions'. Good compliance results were recognised by the senior leadership. In 2009, a one week training programme demonstrated the WHO 5 moments for $\mathrm{HH}$ and the 6 steps to 4000 staff. $\mathrm{HH}$ competence was determined with UV lights and "glogerm". Staff signed a contract and pledged to compliance. Movement activated audio reminders were placedÂ onÂ 3 wards along with posters, hospital wide. On May 5, 2010, a media campaign was launched with a 13 metre high sign posted at the NUH's façade and internal events including awards and a roaming hand mascot.

Medical and nursing students undertake compulsory $\mathrm{HH}$ audits. Candidates in the final medical student (MBBS) clinical examination lose marks for failed compliance.

\section{Results}

We published HH compliance rates of 16\% in 2006 . Through 2010, our rate was 64\% with about 1000

National University Hospital, Singapore, Singapore observed opportunities/month. Our hand rub purchases increased significantly from 391 units (sd 87) in 2006 to 1760 (sd 308) in 2010.

\section{Conclusion}

HH compliance requires active commitment from all, particularly top management. Formal and informal education, stringent audits, public displays and senior management support has significantly raised the $\mathrm{HH}$ compliance in NUH.

\section{Disclosure of interest}

None declared.

Published: 29 June 2011

doi:10.1186/1753-6561-5-S6-P124

Cite this article as: Ang et al.: Improving hand hygiene compliance in Singapore via innovation. BMC Proceedings 2011 5(Suppl 6):P124.

Submit your next manuscript to BioMed Central and take full advantage of:

- Convenient online submission

- Thorough peer review

- No space constraints or color figure charges

- Immediate publication on acceptance

- Inclusion in PubMed, CAS, Scopus and Google Scholar

- Research which is freely available for redistribution

\section{Biomed Central}

(c) 2011 Ang et al; licensee BioMed Central Ltd. This is an open access article distributed under the terms of the Creative Commons Attribution License (http://creativecommons.org/licenses/by/2.0), which permits unrestricted use, distribution, and reproduction in any medium, provided the original work is properly cited. 